[Type here]

\title{
KAJIAN PERUBAHAN HUKUM DAN PEREKONOMIAN PADA ERA PERDAGANGAN BEBAS DI SEKTOR PERTANIAN
}

\author{
Ariani \\ Dosen Universitas Borneo Tarakan \\ Tarakan, Kalimantan Utara, Indonesia \\ Adriana_amk@gmsil.com
}

\begin{abstract}
National economic development has shown the transformation of the economic structure from agriculture to industry, as well as with the development of the law. Economic indicators showed decline in the share of the agricultural sector as well as an increasing share of the industrial sector in the Gross Domestic Product (GDP) can be bukti.Pertanian in Indonesia is at crossroads jalan.Sebagai supporting the livelihood of millions of Indonesian society, the agricultural sector requires a strong economic growth and rapid Sektor also need to be one of the main components in the program and the government's strategy to alleviate structural kemiskinan.Transformasi between sectors, it appears that with increasing per capita income, the agricultural sector has decreased the share of the GDP, while the industrial sector on the contrary experienced peningkatan.Kebanyakan developing countries today this has been agreed that the development of industry and agriculture as much as possible to walk semultan. Agriculture provides a market for manufactured goods, feed the urban population, be a source of labor and capital to the industrial sector, as well as generate foreign exchange for the import of machinery and raw materials required by the intermediate industri.Prioritas sector policies to increase food production can be done through the use teknologi.Tipe and direction of technological change is influenced by market forces and pemerintah.Selain research funded research in the country, the source of technological progress is a transfer from outside negeri.Program-local research programs in countries developing in some ways is not replaceable by technology the foreign research results.
\end{abstract}

Keywords: Structural Transformation, GDP, Agricultural Sector, Industrial Sector

\section{PENDAHULUAN}

Sejak awal tahun 1965-an, yaitu masa stabilitasi ekonomi dengan program repelita yang digulirkan oleh pemerintah orde baru, Indonesia telah merancang pembangunan dengan urutan sebagaimana yang telah dikemukakan oleh Rostow. Tahap-tahap pembangunan ekonomi tersebut dibagi menjadi lima bagian yaitu; tahap masyarakat tradisional, tahap prasyarat untuk lepas landas, tahap lepas landas, tahap gerakan kedewasaan dan tahap konsumsi tinggi. ${ }^{1}$ Urutan pembangunan tersebut pada

1Mahyudi, Ahmad., 2004, h. 2000 
hakekatnya adalah mempersiapkan negara yang lebih maju dengan proses industrialisasi.

Pembangunan ekonomi nasional telah menunjukkan adanya transformasi struktur perekonomian dari sektor pertanian ke sektor industri.Indikator ekonomi yang menunjukkan menurunnya pangsa sektor pertanian serta meningkatnya pangsa sektor industri dalam Produk Domestik Bruto (PDB) dapat menjadi bukti.Pangsa relatif sektor pertanian dalam PDB sebesar 49,3\% pada tahun 1969, menjadi 18,5\% pada tahun 1993 , sedangkan sektor industri meningkat dari 9,2\% menjadi 22,4\% untuk periode yang sama (Wihowo, 1994). Inilah yang serigkali disebut-sebut sebagai "keberhasilan" transformasi.

Namun demikian, pangsa tenaga kerja sektor pertanian belum menurun secara berarti, yaitu sebesar 56 persen pada tahun 1980 dan hanya turun menjadi 48 persen pada tahun 1995. Ketidakseimbangan penurunan pangsa sektor pertanian terhadap PDB dibandingkan dengan penurunannya terhadap total tenaga kerja menunjukkan bahwa sektor pertanian semakin tidak produktif dan tidak efisien. Dari data tersebut bisa terlihat semakin menurunnya pendapatan per kapita tenaga kerja di sektor pertanian.

Pertanian di Indonesia sedang berada dipersimpangan jalan.Sebagai penunjang kehidupan berjuta-juta masyarakat Indonesia, sektor pertanian memerlukan pertumbuhan ekonomi yang kukuh dan pesat.Sektor ini juga perlu menjadi salah satu komponen utama dalam program dan strategi pemerintah untuk mengentaskan kemiskinan.Dimasa lampau, pertanian Indonesia telah mencapai hasil yang baik dan memberikan kontribusi penting dalam pertumbuhan ekonomi di Indonesia, termasuk menciptakan lapangan pekerjaan dan penggurangan kemiskinan secara drastis.Hal ini dicapai dengan memusatkan perhatian pada bahan-bahan pokok seperti beras, jagung, gula dan kacang kedelai.Akan tetapi dengan adanya penurunan tajam dalam hasil produktifitas panen dari hampir seluruh jenis bahan pokok, ditambah mayoritas petani yang bekerja di sawah kurang dari setengah hektar, aktifitas pertanian kehilangan potensi untuk menciptakan tambahan lapangan pekerjaan dan peningkatan penghasilan.

Jika kita pelajari sejarah perekonomian Indonesia sejak masa orde baru hingga kecenderungannya pada era globalisasi pada tahun 2020 nanti, maka akan kita peroleh suatu perkembangan yang "taat azas". Artinya, produk unggulan maupun andalan 
pemasukan devisa (PDB) secara perlahan namun pasti menunjukkan pergeseran dari sektor primer, sekunder dan tersier. Hal ini secara langsung juga membawa pengaruh terhadap perubahan struktur sosial masyarakat, dari budaya pertanian tradisional menjadi budaya industri modern.

Perubahan atau transformasi yang terjadi dalam struktur ekonomi maupun struktur sosial ini sebenarnya merupakan suatu gejala yang sangat wajar bagi perekonomian suatu negara dimanapun, seiring dengan perkembangan teknologi industri serta permintaan masyarakat modern terhadap jasa-jasa pelayanan umum. Meskipun demikian, temtu saja akan terjadi dampak-dampak yang ditimbulkan baik positif maupun negatif.

Dalam kaitan ini, kita perlu berpegang pada suatu "aksioma" bahwa globalisasi perdagangan dan invertasi dunia yang mengarah kepada revolusi 3T (Triple $T$ Revolution), adalah suatu proses alamiah yang pasti terjadi. Dimana yang disebut dengan triple T revolution ialah transportasi, telekomunikasi, dan travel. Oleh karena itu, munculnya dampak negatif tidak harus ditakuti, sebab seluruh pelaku ekonomi nasional maupun pihak pemerintah sendiri memiliki keyakinan yang kuat bahwa dampak positif yang ada lebih banyak dibanding dengan dampak negatifnya. Inilah tantangan kita untuk memanfaatkan proses transformasi bagi kepentingan masyarakat seluruhnya.

\section{RUMUSAN MASALAH}

Berdasarkan latar belakang diatas, maka dapat dirumuskan permasalahan sebagai berikut :

1. Mengetahuibagaimana pengaruh transformasi pertanian dalam pembangunan ekonomi.

2. Mengetahui peranan pertanian dalam pembangunan perekonomian pada Negara sedang berkembang khususnya di Indonesia.

3. Memberikan gambaran perkembangan perubahan struktur ekonomi dalam proses pembangunan dilihat dari sektor pertanian dalam menciptakan produksi nasional dan peningkatan pembangunan pertanian.

\section{PEMBAHASAN}

Sepanjang proses pembangunan ekonomi sektor pertanian mengalami transformasi, baik internal sektor pertanian maupun eksternal dalam hubungannya dengan sektor-sektor perekonomian lain. Yang dimaksudtransformasi internal misalnya perubahan pemilihan jenis tanaman dari tanaman pangan untuk kebutuhan sendiri 
(subsisten) menjadi tanaman untuk dijual ke pasar (komersial), atau transformasi dari peralatan pertanian manual keperalatan mesin.Sedangkan transformasi eksternal adalah semakin menurunnya peran pertanian dalam sumbangannya terhadap PDB maupun daya serapnya terhadap tenaga kerja.

Ada tiga tahap pembangunan pertanian.Tahap pertama adalah pertanian tradisional yang produktivitasnya rendah.Tahap kedua adalah tahap penganekaragaman produk pertanian, sudah mulai terjadi dimana produk pertanian sudah ada yang dijual ke sektor komersial, tetapi pemakaianmodal dan teknologi masih rendah.Tahap yang ketiga adalah tahap yang menggambarkan pertanian modern yang produktivitasnya sangat tinggi yang disebabkan oleh pemakaian modal dan teknologi yang tinggi pula.Pada tahap ini produk pertanian seluruhnya ditujukan untuk melayani keperluan pasar komersial.

Modernisasi pertanian dari tahap tradisional (subsisten) menuju pertanian modern membutuhkan banyak upaya lain selain pengaturan kembali struktur ekonomi pertanian atau penerapan teknologi pertanian yang baru. Setiap pemerintah yang berusaha mentransformasi pertanian tradisional haruslah menyadari bahwa pemahaman akan perubahan-perubahan yang mempengaruhi seluruh aspek baik sosial, politik, dan kelembagaan masyarakat pedesaan adalah sangat penting. Tanpa adanya perubahan-perubahan seperti itu, pembangunan pertanian tidak akan pernah bisa berhasil seperti yang diharapkan.

$\operatorname{Arsyad}^{2}$ menyatakan bahwa pertanian mengalami tahap-tahap perkembangan atau transformasi sebagai berikut :

- Tahap Pertanian Subsisten, yaitu suatu tahap dimana produksi dan konsumsiberjumlah seimbang sehingga tidak ada kelebihan yang bisa dijual ke pasar. Jenis tanaman terbatas pada beberapa tanaman bahan pangan pokok seperti padi, jagung, dan ketela. Produksi dan produktivitas rendah karena menggunakan peralatan sederhana dengan teknologi rendah. Modal digunakan dalam jumlah yang sangat kecil sementara yang mendominasi adalah tanah dan tenaga kerja manusia. Pada tahap ini motif utama para petani adalah untuk bertahan hidup, bukan untuk meningkatkan produktivitas, karena bagi mereka tanah pertanian - yang biasanya sempit - adalah mati hidupnya keluarganya sehingga mereka sangat takut akan resiko gagal panen, dan akibatnya mereka 
sangat sukar berpindah ke teknologi baru yang belum mereka ketahui kemungkinan keberhasilannya. Mereka lebih memilih teknologi sederhana yang sudah mereka gunakan berates tahun dan telah terbukti berhasil meskipun produktivitasnya rendah.

- Tahap Transisi, yaitu tahap perpindahan dari pertanian subsisten ke pertanian modern. Seiring dengan tersebarnya informasi dan bertambahnya pendidikan diantara keluraga petani, minat mereka akan jenis tanaman serta teknologi baru dan penggunaan modal dalam proses pertanian mereka semakin besar. Tetapi langkah yang mereka untuk mengembangkan pertanian biasanya tidak drastis, dalam arti mereka berpindah secara bertahap. Tanaman bahan pokok masih tetap ditanam, tetapi mereka mulai menanam jenis tanaman lain yang bisa dijual di pasar. Beberapa peralatan mekanis seperti traktor kecil mulai digunakan. Para petani miskin yang melihat tetangganya yang lebih berani telah menggunakan bibit dan pupuk buatan dan melihat bahwa hasil panennya lebih tinggi mulai berani ikut menggunakannya.

- Tahap Pertanian Modern, yaitu tahap dimana jenis tanaman yang dibudidayakan murni ditujukan untuk pasar. Modal dan peralatan mekanis serta penggunaan bibit dan pupuk buatan serta obat serangga dan hama tanaman mendominasi pertanian. Proses produksi dikendalikan oleh sebuah manajemen yang mengontrol proses pertanian dan juga harga serta kondisi bisnis di perekonomian secara umum. Pada tahap ini pertanian tidak ubahnya sebuah perusahaan sehingga lazim disebut sebagai agroindusti. Tahap ini belum bisa dicapai oleh kebanyakan Negara berkembang sekarang ini.

Ditinjau dari seluruh sektor pertanian secara total, transformasi terjadi dalam bentuk turunnya sumbangan pertanian dalam GDP dan kesempatan kerja yang diciptakannya. Ini bisa terjadi karena dengan meningkatnya standar hidup masyarakat secara umum, kebutuhan konsumsi barang dan jasa non-pangan meningkat, sehingga meningkatkan proporsi sumber daya yang dialokasikan untuk proses produksi sektor non-pertanian.

Di Negara-negara kaya seperti Eropa Barat dan Amerika Serikat, angkatan kerja disektor pertanian terhitung kurang dari 10 persen, sementara di Negara-negara berkembang kesempatan kerja disektor non-pertanian sekitar 30 persen.Gambaran tersebut menjadi persepsi dasar tentang bagaimana pembangunan seharusnya berjalan. 
Dalam struktur ekonomi pasti akan mengalami perubahan dalam proses pembangunan ekonomi, sudah lama disadari oleh ahli-ahli ekonomi. Tulisan A.G.B.Fisher ${ }^{3}$ dalam International Labour Review pada tahun 1935 telah mengemukakan pendapatbahwa berbagai negara dapat dibedakan berdasarkan persentase tenaga kerja yang berada di sektor primer, sekunder, dan tersier. Pendapat ini dibuktikan oleh Clark ${ }^{4}$ yang telah mengumpulkan data statistik mengenai persentase tenaga kerja yang bekerja disektor primer, sekunder dan tersier dibeberapa negara.Data yang dikumpulkannya itu menunjukkan bahwa makin tinggi pendapatan per kapita suatu negara, makin kecil peranan sektor pertanian dalam menyediakan kesempatan kerja.Akan tetapi sebaliknya, sektor industri makin penting peranannya dalam menampung tenaga kerja.

Untuk mengetahui berbagai corak perubahan dalam struktur ekonomi pada masa yang lalu, Kuznets menggumpulkan data mengenai sumbangan berbagai sektor kepada produksi nasional di tiga belas negara yang sekarang ini termasuk ke dalam golongan atau kelompok negara maju (Inggris, Perancis, Jerman, Belanda, Denmark, Norwegia, Swedia, Italia, Amerika Serikat, Kanada, Australia, Jepang, dan Rusia).Salah satunya sumbangan sektor pertanian kepada produksi nasional yang telah menurun di dua belas dari tiga belas negara ada.Umumnya pada taraf permulaan pembangunan ekonomi, peranan sektor itu mendekati setengah dan adakalanya mencapai sampai hampir dua per tiga dari seluruh produksi nasional.

Pada akhir masa observasi, peranan sektor pertanian dikebanyakan negara dalam menghasilkan produksi nasional hanya mencapai 20 persen atau kurang dan dibeberapa negara perannya lebih rendah dari 10 persen. Dengan demikian, dalam proses pembangunan, peranan sektor pertanian telah menurun paling sedikit sebesar 20 persen (misal dari mula menyumbang 50 persen, sekarang hanya 30 persen saja, maka dikatakanlah bahwa peranannya telah menurun sebesar 20 persen) dan adakalanya sampai mencapai 30 persen. Satu-satunya pengecualian dari keadaan ini adalah perubahan yang terjadi di Australia; dalam delapan dasawarsa peranan sektor pertanian bertambah besar, walaupun dalam jangka masa itu kemajuan ekonominya terus-menerus berlangsung.

Sedang dalam sektor industri menghasilkan produksi nasional meningkat paling sedikit berkisar antara 20 sampai 30 persen dari produksi nasional dan untuk sektor

3Sadono Sukirno, 2007, h. 144 (A.G.B. Fisher, 1935, International Labour Review)

${ }^{4}$ C.Clark, The Condition of Economic progress, MacMillan, London, 1949, Bab 5 
jasa dalam menciptakan pendapatan nasional tidak mengalami perubahan yang berarti dan perubahan itu tidak konsisten sifatnya. Perubahan corak struktur ekonomi seperti yang telah digambarkan diatas mempunyai arti bahwa produksi sektor pertanian mengalami perkembangan yang lebih lambat ketimbang perkembangan produksi nasional.

Perubahan struktur ekonomi yang demikian coraknya disebabkan oleh beberapa faktor antara lain sebagai berikut :

1. Keadaan yang demikian disebabkan oleh sifat manusia dalam kegiatan konsumsinya, yaitu apabila pendapatan naik, elastisitas permintaan yang diakhibatkan oleh perubahan pendapatan (income elasticity of demand) adalah rendah untuk konsumsi atas bahan-bahan makanan. Sedangkan permintaan terhadap bahan-bahan pakaian, perumahan dan barang-barang konsumsi hasil industri keadaannya adalah sebaliknya.

2. Kemajuan teknologi menyebabkan pula perubahan dalam struktur produksi nasional yang bersifat compulsory dan inducive, yaitu kemajuan tersebut menciptakan barang-barang-barang baru yang menambah pilihan barangbarang yang dapat dikonsumsi masyarakat.

3. Peranan produksi industri dalam produksi nasional juga disebabkan oleh karena negara maju yang mengalami kemajuan tersebut telah memperoleh keunggulan komparatif (comparative advantage) dalam menghasilkan barang-barang industri.

Peranan sektor pertanian dalam pembangunan ekonomi sangat penting karena sebagian besar anggota masyarakat dinegara-negara miskin menggantungkan hidupnya pada sektor tersebut. Jika para perencana dengan sungguh-sungguh memperhatikan kesejahteraan masyarakatnya, maka satu-satunya cara adalah dengan meningkatkan kesejahteraan sebagian besar anggota masyarakatnya yang hidup di sektor pertanian itu. Cara ini bisa ditempuh dengan jalan meningkatkan produksi tanaman pangan dan tanaman perdagangan mereka dan atau dengan menaikkan harga yang mereka terima atas produk-produk yang mereka hasilkan. Tentu saja tidak setiap kenaikkan output akan menguntungkan sebagian besar penduduk pedesaan yang bergerak di bidang pertanian itu.

Hampir semua NSB mengandalkan sektor pertanianmereka untuk kebutuhan negara mereka.Tentu saja ada perkecualian, misalnya Malaysia atau Saudi Arabia. 
Kedua negara ini, yang kaya akan sumber daya alam untuk ekspor (timah dan minyak), mempunyai cadangan devisa yang banyak untuk mengimpor kebutuhan-kebutuhan pangan mereka.

Ukuran sektor pertanian menjadikan sektor ini mempunyai peranan penting dalam menyediakan input, yaitu tenaga kerja, bagi sektor industri dan sektor-sektor modern lainnya. Sebagian besar (70 persen atau lebih) populasi pada sektor pertanian pedesaan merupakan sumber utama bagi kebutuhan tenaga kerja yang meningkat di sektor perkotaan.Pemasukan tenaga kerja ke perkotaan adalah mungkin, dan disamping itu biasanya ada kenaikan penduduk disektor perkotaan itu sendiri, tetapi tidak ada satupun dari kedua sumber ini yang dapat mencukupi kebutuhan pertumbuhan ekonomi sepanjang waktu. Jika ada pembatasan keluarnya tenaga kerja dari pertanian, maka pembangunan ekonomi akan timpang.

Sektor pertanian juga dapat merupakan sumber modal yang utama bagi pertumbuhan ekonomi modern.Modal berasal dari tabungan yang di investasikan dan tabungan berasal dari pendapatan.Di negara-negara yang paling miskin, pangsa pendapatan pertanian terhadap produk nasional mencapai 50 persen. Berarti separuh atau lebih dari produk nasional disumbangkan oleh sektor non-pertanian, terutama industri dan perdagangan (jasa-jasa), dan sektor-sektor ini merupakan penyumbang penting bagi tabungan yang akhirnya digunakan untuk investasi.

Jika orang membicarakan cadangan devisa sebagai faktor produksi yang terpisah, maka pertanian berperan penting dalam menghasilkan faktor ini. Seperti diketahui, NSB biasanya mempunyai keunggulan komparatif untuk produk- produk mineral dan pertanian.Hanya sedikit sekali negara, yang pada awalnya pertumbuhan ekonominya, yang sumber devisanya berasal dari industri manufaktur dan jasa-jasa. Oleh karena itu, jika suatu negara yang kaya akan sumber-sumber mineral seperti minyak misalnya, maka sektor pertanian harus memerankan peranan kunci dalam menyediakan devisa yang digunakan untuk mengimpor barang-barang modal yang belum dapat diproduksi sendiri.

Akhirnya, penduduk pertanian pedesaan di NSB, paling tidak dalam beberapa kasus merupakan pasar yang penting bagi output dari sektor modern perkotaan. Istilah "dalam beberapa kasus" harus ditambahkan karena penduduk pertanian pedesaan dalam beberapa negara miskin hanya sedikit sekali membeli hasil-hasil industri modern.Hal ini sebenarnya menunjukkan pula bahwa pembagian pendapatan yang 
tidak merata, dimana sebagian besar pendapatan nasional dan kekayaan berada ditangan kelompok-kelompok elit di perkotaan dan kelas atas ke pedesaan.

Pertanian memperoleh energi dari sinar matahari dan prosesnya melalui prosesproses biologis dari pertumbuhan hewan dan tanaman.Pertanian dikelolah oleh para petani, dan para petani ini adalah manusia-manusia dan anggota-anggota keluarga serta anggota masyarakat setempat.

Namun demikian, pembangunan pertanian tidak dapat dilaksanakan hanya oleh petani sendiri.Pertanian tidak dapat berkembang melampaui tahap subsisten (tradisional) tanpa adanya perkembangan yang sesuai pada bidang-bidang kehidupan nasional lainnya dari masyarakat dimana pertanian itu dilaksanakan.Untuk meningkatkan produktivitas pertanian, setiap petani semakin lama semakin tergantung pada sumber-sumber dari luar lingkungannya. Ia meningkatkan kadar kesuburan tanah dengan menambahkan pupuk pada lahan pertaniannya.

A.T. Mosher ${ }^{5}$ (1965) menganalisis syarat-syarat pembangunan pertanian jika pertanian akan dikembangkan dengan baik. Mosher mengelompokkan syarat-syarat pembangunan tersebut menjadi dua yaitu syarat-syarat pelancar.Menurut Mosher ada 5 yang tidak boleh tidak harus ada (syarat mutlak) untukadanya pembangunan pertanian.Kalau satu-satu saja diantara syarat-syarat tersebut tidak ada, maka terhentilah pembangunan pertanian-pertanian bisa berjalan tetapi statis. Syarat-syarat mutlak itu menurut Mosher adalah :

1. Adanya pasar untuk hasil-hasil usaha tani

Pembangunan pertanian akan meningkatkanproduksi hasil-hasil usaha tani. Hasil-hasil ini tentunya akan dipasarkan dan dijual dengan harga yang cukup tinggi untuk menutupi biaya dan tenaga yang telah dikeluarkan para petani sewaktu memproduksinya.

2. Teknologi yang senantiasa berkembang

Meningkatnya produksi pertanian diakibatkan oleh pemakaian cara-cara atau teknik-teknik baru didalam usaha tani."Teknologi pertanian” berarti, cara-cara bertani, didalamnya termasuk cara-cara bagaimana para petani menyebarkan benih, memelihara tanaman dan memungut hasil serta memelihara ternak. Termasuk pula didalamnya benih, pupuk, obat-obatan pemberantas hama, alatalat dan sumber-sumber tenaga. Juga termasuk berbagai kombinasi jenis-jenis 
usaha oleh para petani agar dapat menggunakan tenaga dan tanah mereka sebaik mungkin.

3. Tersedianya bahan-bahan dan alat-alat produksi secara lokal

Sebagian metode baru yang dapat meningkatkan produksi pertanian memerlukan penggunaan bahan-bahan dan alat-alat produksi yang khusus oleh para petani.Pembangunan pertanianmemerlukan factor pendukung dalam pertanian agar tersedia diberbagai tempat dalam jumlah yang cukup banyak untuk memenuhi kebutuhan tiap petani yang menggunakannya.

4. Adanya perangsang produksi bagi petani

Teknologi yang telah maju, pasar yang mudah, dan tersedianya bahan-bahan dan alat-alat produksi, kesemuanya memberikan kesempatan kepada para petani untuk menaikkan produksi.Faktor perangsang utama yang membuat para petani bergairah untuk meningkatkan produksinya adalah perangsang yang bersifat ekonomi.Faktor perangsang tersebut adalah harga hasil produksi pertanian yang menguntungkan, pembagian hasil yang wajar, dan tersedianya barang-barang dan jasa yang ingin dibeli oleh para petani untuk keluarganya.

5. Tersedianya pengangkutan yang lancar dan kontinyu

Syarat mutlak kelima adalah pengangkutan.Tanpa pengangkutan yang efisien dan murah, keempat syarat mutlak lainnya tidak dapat berjalan dengan efektif, karena produksi pertanian harus tersebar luas.Oleh karena itu diperlukan jaringan pengangkutan yang bercabang luas untuk membawa bahan-bahan perlengkapan produksi ke tiap usaha tani dan membawa hasil usaha tani ke kota-kota besar dan kecil.

Disamping kelima syarat mutlak itu, menurut Mosher ada lima syarat lagi yang adanya tidak mutlak tetapi kalau ada (atau dapat diadakan) benar-benar akan sangat memperlancar pembangunan pertanian. Yang termasuk syarat-syarat atau sarana pelancar adalah :

1. Pendidikan Pembangunan

Pendidikan pembangunan disini dititik beratkan pada pendidikan nonformal yaitu berupa khursus-khursus, pelatihan, penyuluhan, dan sebagainya.Pendidikan pembangunan ini bertujuan untuk meningkatkan produktivitas petani.

2. Kredit Produksi 
Untuk meningkatkan produksi, para petani harus lebih banyak mengeluarkan uang untuk membeli bibit unggul, obat-obatan pemberantas hama, pupuk dan alat-alat lainnya.Pengeluaran tersebut harus dibiayai dari tabungan atau dengan meminjam uang dengan jangka waktu antara saat bahan-bahan produksi dan peralatan itu dibeli dan saat hasil panen dapat dijual. Oleh karena itu lembagalembaga perkreditan yang memberikan krdit produksi kepada para petani merupakan suatu faktor pelancar yang penting bagi pembangunan pertanian.

3. Kegiatan Gotong-Royong Petani

Kegiatan gotong-royong petani biasanya dilakukan secara informal.Para petani bekerjasama dalam menanam tanaman mereka atau dalam memanen hasil panen.Mereka bekerjasama dalam membantu tetangga petani yang sedang sakit. Mereka bersatu dalam menangulangi bencana-bencana yang mendadak seperti: banjir, angin topan, serangan hama, dan sebagainya. Kegiatan seperti ini juga dapat memperlancar pembangunan pertanian.

4. Perbaikan dan Perluasan Tanah Pertanian

Ada dua cara tambahan untuk mempercepat pembangunan pertanian yaitu: petama, memperbaiki mutu tanah yang telah menjadi usaha tani, misalnya dengan pupuk, irigasi dan pengaturan pola tanam. Kedua, mengusahakan tanah baru, misalnya membuka petak-petak sawah baru (ekstensifikasi).

\section{Perencanaan Nasional Pembangunan Pertanian}

Perencanaan pertanian adalah proses memutuskan apa yang hendak dilakukan pemerintah mengenai tiap kebijaksanaan dan kegiatan yang mempengaruhi pembangunan pertanian selama jangka waktu tertentu.

Pengalaman sejarah di sejumlah negara dengan terobosan teknologis Revolusi Hijau beberapa dekade terakhir membenarkanperlunya meningkatkan produktivitas faktor produksi.Pengalaman Jepang dan Taiwan menunjukkan bahwa keberhasilan penerapan inovasi - berdasarkan teknologi modern - yang tepat bisa mengembangkan sektor pertanian. ${ }^{6}$ Pengembangan ini ditandai dengan meningkatnya produktivitas faktor-faktor produksi di seluruh sector pertanian.Oleh karena itu diperlukan berbagai langkah aktif untuk membangun pertanian dengan suatu strategi tertentu.

Strategi yang menggunakan input baru berupa bibit dan pupuk buatan (komponen penting Revolusi Hijau) ini bersifat komplementer dengan tenaga kerja 
yang telah ada dipertanian sehingga kenaikan dalam produktivitas faktor produksi bisa mempunyai pengaruh yang sedemikian besar pada output total pertanian, atau dengan kata lain hasil dari kenaikan ekonomi terbagi secara luas, tetapi tidak mengurangi partisipasi petani dalam proses produksi.

Meskipun demikian strategi yang sukses di negara satu belum tentu sukses diterapkan di negara lain. Dengan kata lain analisis strategi pembangunan pertanian harus berhati-hati dalam membuat generalisasi, misalnya kasus Revolusi Hijau (Green Revolution) yang sukses di Asia Selatan dan Asia Timur, ternyata sulit diaplikasikan di sub-Sahara Afrika dan beberapa negara Amerika Latin. Beberapa kriteria pokok tentang strategi perlu dipertimbangkan, yaitu strategi pembangunan yang harus terintegrasi dengan pembangunan total perekonomian, perlu insentif barang-barang konsumsi, serta - yang sedang mengemukakan - pilihan antara strategi bimodal dan unimodal.

Selain itu kebijakan harga di sektor pertanian seperti kredit pada petani dan subsidi harga bahan pangan merupakan hal yang umum di negara-negara berkembang.Penggenaan dua tipe kebijakan harga tersebut, ditambah dengan pajak atas tanaman ekspor, jika tidak didasari informasi dan perhitungan yang tepat dan berhati-hati bisa jadi justru merugikan beberapa kelompok dalam masyarakat.

Kebijakan pertanian sebaiknya dibedakan dengan kebijakan pangan meskipun hasilnya berkaitan.Kebijakan pertanian berhubungan dengan organisasi kinerja system produksi pertanian (pangan dan non-pangan), sementara kebijakan pangan berhubungan dengan pemenuhan nutrisi dan konsumsi pangan. Kebijakan pangan berupa penetapan harga bahan pangan murah (supaya tingkat upah perekonomian tetap rendah serta menolong para miskin) juga akan berpengaruh terhadap kebijakan harga pertanian (menyebabkan pendapatan petani menjadi lebih sedikit). Begitu juga kebijakan nasional memajaki impor produk pertanian, atau kebijakan ekspansi industriindustri tekstil, juga akan mempengaruhi harga produk pertanian, meskipun kali ini bersifat menguntungkan petani. Kebijakan harga yang dikenakan pada produsen pertanian di negara-negara berkembang lebih bersifat pemajakan, bukan subsidi.

Idealnya pembuatan kebijakan pertanian disesuaikan dengan kebijakan di sektor publik dan industri karena adanya keterkaitan satu dengan lainnya. Pada tahun-tahun 1950-an dan tahun 1960-an kebijakan pembangunan di negara-negara berkembang menekankan perlunya pemanfaatan surplus pertanian untuk diinvestasikan di sektor perekonomian lainnya (sektor industri) yang sedang berekspansi. 
Beberapa skema pemindahan surplus sektor pertanian ke perekonomian secara keseluruhan bisa dilihat di bawah ini;

1) Surplus berupa bahan pangan yang ditransfer ke sektor lain dengan harga yang rendah

2) Produksi tanaman pangan dan tanaman ekspor yang dipromosikan sebagai sumber devisa dan sekaligus media untuk pemajakan

3) Tabungan dan pajak dari sektor pertanian yang diinvestasikan di sektor nonpertanian

4) Surplus tenaga kerja yang bisa ditarik ke sektor non-pertanian

5) Penetapan dasar tukar yang tidak menguntungkan pertanian dengan cara menahan harga produk pertanian [batas harga rendah (floor price) dan batas harga tinggi (ceiling price)].

Selain itu Schiff dan Valdes ${ }^{7}$, merekomendasikan kebijakan untuk menghilangkan distorsi harga pertanian berikut ini :

1. Jika sebuah negara mencapai pertumbuhan pertanian dan ekonomi yang lebih cepat, serta mengurangi kemiskinan, dia harus menghentikan pemungutan pajak pertanian, relatif terhadap sektor yang lain.

2. Untuk menghentikan pemungutan pajak terhadap sektor pertanian, sebuah negara harus menghilangkan proteksi yang berlebihan atas sektor industri dan menghilangkan intervensi dalam harga pertanian.

3. Jika sebuah negara ingin mendapat manfaat yang besar dari reformasi pertanian maka harus menghentikan kebijakan pemungutan pajak ekspor produk pertanian dan melindungi impor barang pertanian.

4. Jika sebuah negara ingin bisa transparan, hal yang penting untuk reformasi harga yang efektif - sehingga dia mengetahui siapa yang menjadi pihak kena pajak dan siapa pihak yang menang dan siapa yang kalah - dia harus menghilangkan kuota, lisensi dan mekanisme perdagangan negara.

5. Jika sebuah negara ingin menstabilkan harga, maka negara tersebut harus menggembangkan instrument hedging yang efisien, mereformasi kebijakan pertanian, dan menghentikan pengaruh elit penguasa yang mendistorsi harga.

${ }^{7}$ Schiff, M, dan Valdes, A., The plundering of Agriculture in developing Countries, 1982, dalam Colman, 1994, hal. 227 
6. Untuk mencapai manfaat yang penuh dari reformasi harga dan perdagangan pertanian, sebuah negara harus mereformasi bidang pemasaran dan distribusi atas input, output pertanian serta barang-barang konsumen di pedesaan dan juga reformasi tambahan atas transfortasi, komunikasi, dan tanah, tenaga kerja dan pasar kredit.

Pemahaman terhadap sektor pertanian sangat penting dalam memahami pembangunan ekonomisecara keseluruhan. Alasan lebih kuat lagi untuk memberikan perhatian besar pada pembangunan pertanian dikarenakan pertanian merupakan mata rantai terlemah dalam rantai pembangunan di negara-negara berkembang. Sektor industri di Negara-negara berkembang telah tumbuh dengan tingkat kurang lebih 7 persen per tahun, jumlah anak-anak yang pergi ke sekolah meningkat 4 kali lipat setiap tahunnya, rasio tabungan domestik meningkat 3 persen per tahun. Tetapi gambaran yang cerah tersebut menjadi suram ketika kita beralih ke sektor pertanian, dimana produksi secara keseluruhan negara-negara berkembang telah gagal dalam mengimbangi permintaan pangan, dan menyebabkan masalah-masalah yang lain dalam perekonomian.

Alasan bagi buruknya kinerja sektor pertanian tersebut bisa diberikan sebagai berikut : pertama, pertumbuhan populasi yang cepat, sekitar 2,5 persen per tahun, telah mendorong permintaan pangan pada tingkat lebih dari 3 persen sementara pertumbuhan produksi pangan kurang dari tingkat tersebut, sehingga sektor pertanian yang diharapkan menjadi salah satu dari tingkat tersebut, sehingga sektor pertanian yang diharapkan menjadi salah satu sektor penyumbang devisa (ekspor pangan) sekarang justru menjadi sektor yang menghabiskan devisa (impor pangan). Kedua, revolusi teknologi dalam bidang produksi pangan tropis baru saja dimulai dan masih menjumpai berbagai kendala dalam implementasinya, misalnya menyangkut perilaku petani kecil yang sukar berpindah keteknologi baru dengan berbagai alasannya, jugga sarana pendukung di Negara-negara berkembang yang belum memadai.Ketiga, pola kepemilikan tanah di negara berkembang tidak merata, dimiliki oleh sedikit tuan tanah sementara sebagian besar petani hanya memiliki jumlah tanah yang sangat sempit, banyak yang kurang dari satu hektar. Terakhir, dasar tukar produk pertanian tampak semakin hari semakin turun dibanding produk non-pertanian dan hal ini menurunkan minat petani untuk berproduksi lebih banyak dan lebih memilih untuk berpindah ke sektor lain. 
Kadang-kadang atau pada umumnya orang mengatakan bahwa di negara-negara sedang berkembang investasi pada sektor industri adalah yang terpenting, untuk memaksimumkan kenaikkan output.Tetapi bila penduduk ditarik dari sektor pertanian untuk bekerja di sektor industri yang baru mereka ini toh masih harus makan. Karena itu harus ada usaha-usaha lain di sektor pertanian untuk menyediakan bahan makanan bagi mereka yang pindah dan bekerja ke sektor industri. Lagipula dengan naiknya pendapatan ada tambahan penduduk dan mereka harus diberi makan, sehingga tambahan produksi bahan makanan harus ada, untuk mengimbangi tambahan pemduduk dan bertambahnya permintaan akan bahan makanankarena naiknya pendapatan. Hal ini dikarenakan tingkat "income elasticity of demand" di negara-negara sedang berkembang masih cukup tinggi; kira-kira 0,6 persen. Oleh karena itu bagi negara-negara yang masih terbelakang sektor pertanian sebenarnya adalah sektor yang terpenting.

Oleh karena itu peranan sektor pertanian dalam pembangunan ekonomi sangat penting karena sebagian besar anggota masyarakat di negara-negara miskin menggantungkan hidupnya pada sektor tersebut. Jika para perencana dengan sungguhsungguh memperhatikan kesejahteraan masyarakatnya, maka satu-satunya cara adalah dengan meningkatkan kesejahteraan sebagian besar anggota masyarakatnya yang hidup di sektor pertanian itu. Cara ini bisa ditempuh dengan jalan meningkatkan produksi tanaman pangan dan tanaman perdagangan mereka dan atau dengan menaikkan harga yang mereka terima atas produk-produk yang mereka hasilkan. Tentu saja tidak setiap kenaikkan output akan menguntungkan sebagian besar penduduk pedesaan yang bergerak di bidang pertanian itu.

\section{Pengaruh transformasi pertanian dalam pembangunan ekonomi}

Sepanjang proses pembangunan ekonomi sektor pertanian mengalami transformasi, baik internal sektor pertanian maupun eksternal dalam hubungannya dengan sektor-sektor perekonomian lain. Yang dimaksud transformasi internal misalnya perubahan pemilihan jenis tanaman dari tanaman pangan untuk kebutuhan sendiri (subsisten) menjadi tanaman untuk dijual ke pasar (komersial), atau transformasi dari peralatan pertanian manual keperalatan mesin.Sedangkan transformasi eksternal adalah semakin menurunnya peran pertanian dalam sumbangannya terhadap PDB maupun daya serapnya terhadap tenaga kerja. 
Tujuan mengidentifikasi pola transformasi adalah mendapatkan gambaran pola transformasi struktural dalam sebuah perekonomian, khususnya gambaran kaitan perubahan antar sektor untuk membantu menyusun kerangka kebijakan yang lebih efektif untuk mempercepat pembangunan dan mengatasi kendala bagi berlangsungnya perubahan tersebut.Karena itu setelah menganalisi aspek-aspek umum transformasi struktural dalam pembangunan, khususnya yang berhubungan dengan pertanian.

Dalam mentransformasi sektor pertanian saat ini, negara-negara berkembang biasanya mengacu pola sejarah pembangunan negara-negara maju.Tetapi harus diperhatikan bahwa keadaan negara-negara maju sebelum mereka membangun industrinya berbeda dengan keadaan negara-negara berkembang saat ini. Meskipun demikian terdapat juga ciri-ciri yang serupa, misalnya kecenderungan ter jadinya migrasi dari desa ke kota, atau semakin kecilnya daya tukar relative produk pertanian terhadap produk industri yang memungkinkan adopsi kebijakan yang telah dilakukan nnegara maju di negara berkembang.

Perubahan hubungan antara sektor pertanian dan non-pertanian dari sisi kontribusi pertanian terhadap pembangunan bisa didaftarkan seperti dibawah ini.

1) Pertanian menyumbang - dengan jumlah yang semakin meningkat - kebutuhan pangan populasi non-pertanian yang sedang meningkat.

2) Sektor pertanian semakin menggurangi jenis tanaman pangan dan semakin banyak menanam jenis tanaman industri yang merupakan input dasar proses industri, terutama industri pangan di perkotaan.

3) Sektor pertanian menyumbang factor produksi berupa tenaga kerja dan modal.

4) Ekspor pertanian dari waktu ke waktu merupakan sumber devisa untuk membeli peralatan kapital dari luar negeri serta mengimpor barang konsumsi yang tidak diproduksi di dalam negeri.

5) Sektor pedesaan menyediakan sumber dana untuk investasi industri di perkotaan. Prosesnya bisa melalui pemajakan yang dilakukan pemerintah dan dialikasikan untuk membangun prasarana industry di perkotaan, bisa juga melalui tabungan sukarela petani di system perbankan yang pada akhirnya digunakan untuk investasi kesektor industry.

6) Meningkatkan permintaan akan produk industri dan dengan demikian mendorong diperluasnya sektor sekunder dan tersier. Dengan kata lain menyediakan pasar bagi output sektor industri. 
7) Memperbaiki kesejahteraan penduduk pedesaan yang merupakan masalah utama pembangunan di negara-negara berkembang.

Jika kita perhatikan transformasi struktural antar sektor, tampak bahwa seiring meningkatnya pendapatan per kapita, sektor pertanian mengalami penurunan pangsa terhadap GDP sedangkan sektor industri sebaliknya mengalami peningkatan.Kebanyakan negara berkembang saat ini telah sepakat bahwa pembangunan industri dan pertanian sebisa mungkin harus berjalan semultan. Pertanian menyediakan pasar bagi barang-barang manufaktur, memenuhi kebutuhan pangan penduduk perkotaan, menjadi sumber tenaga kerja dan capital untuk sektor industri, serta menghasilkan devisa untuk impor mesin-mesin dan bahan baku intermediate yang diperlukan oleh sector industri. Sebaliknya sektor industri menyediakan suplai input (traktor, bibit unggul, puatan dan sebagainya) yang diperlukan untuk memodernisir sector pertanian, menyediakan barang-barang yang dibutuhkan oleh penduduk sector pertanian di pedesaan, serta menjadi pasar bagi output pertanian baik dalam bentuk konsumsi (beras, gandum) maupun sebagai input proses produksi untuk diproses lebih lanjut (kapas untuk tekstil).

Kajian terhadap perekonomian Indonesia, secara ilmiah baru bisa dilaksanakan semenjak lahirnya Orde Baru.Hal ini disebabkan pada masa-masa sebelumnya, pemerintah cenderung bersikap tertutup dalam kebijakan ekonominya.Disamping itu, kondisi politik keamananyang belum mantap, menyebabkan tingkat perkembangan ekonomi menjadi terhambat. Inilah yang menjadikan kondisi perekonomian Indonesia pada pertengahan dasawarsa 1960-an sebagai suatu masa suram. Sektor Industri yang menyumbang hanya $10 \%$ dari GDP dihadapkan pada masalah pengangguran kapasitas yang serius pada tahun 1966. Pada masa ini defisit anggaran belanja negara mencapai $50 \%$ dari pengeluaran total negara, ditambah lagi dengan penerimaan ekspor sangat menurun serta hiperinflasi periode 1964-1966, menjadikan Indonesia mengalami kelumpuhan perekonomian.

Meskipun demikian, menjelang tahun 1977 perekonomian Indonesia telah mengalami perubahan structural yang cukup menyolok, sebagai akhibat kebijaksanaan pemerintah yang ditunjang oleh naiknya harga minyak bumi. Selama dasawarsa setelah tahun 1965, bagian GDP atau PDB yang berasal dari sector pertanian turun dari $\pm 52 \%$ menjadi $\pm 35 \%$, sedangkan bagian GDP yang berasal dari sector pertambangan telah melonjak dari $\pm 3,7 \%$ menjadi $\pm 12 \%$. 
Jadi transformasi ssecara struktural bukan berarti meninggalkan sektor pertanian menuju sektor industri, tetapi menjadikan pangsa sektor industri terhadap PDB yang lebih besar dari sektor pertanian, yang disebabkan oleh pertumbuhan sektor industri yang lebih tinggi akhibat faktor eksternalitas industrialisasi yang lebih besar.

Setidaknya ada beberapa faktor yang bisa diungkapkan bahwa sektor pertanian menjadi penting dalam proses pembangunan, yaitu :

1. Sektor pertanian menghasilkan produk-produk yang diperlukan sebagai input sektor lain, terutama sektor industri, seperti : industri tekstil, industri makanan dan minuman.

2. Sebagai negara agraris (kondisi historis) maka sektor petanian menjadisektor yang sangat kuat dalam perekonomian dalam tahap awal proses pembangunan. Populasi di sektor pertanian (pedesaan) membentuk suatu proporsi yang sangat besar. Hal ini menjadi pasar yang sangat besar bagi produk-produk dalam negeri baik untuk barang produksi maupun barang konsumsi, terutama produk pangan. Sejalan dengan itu, ketahanan pangan yang terjamin merupakan prasyarat kestabilan sosial dan politik.

3. Karena terjadi transformasi struktural dari sektor pertanian ke sektor industri maka sektor pertanian menjadi sektor penyelia faktor produksi (terutama tenaga kerja) yang besar bagi sektor non pertanian (industri).

4. Sektor pertanian merupakan SDA yang memiliki keunggulan komparatif di banding bangsa lain. Proses pembangunan yang ideal mampu menghasilkan produk-produk pertanian yang memiliki keunggulan kompetitif terhadap bangsa lain, baik untuk kepentingan ekspor maupun substitusi impor (Tambunan, 2001).

Peranan sektor pertanian dalam pembangunan ekonomi sangat penting karena sebagian besar anggota masyarakat di negara-negara miskin menggantungkan hidupnya pada sektor tersebut. Jika para perencana dengan sungguh-sungguh memperhatikan kesejahteraan masyarakatnya, maka satu-satunya cara adalah dengan meningkatkan kesejahteraan sebagian anggota masyarakatnya yang hidup disektor pertanian itu. Cara ini bisa ditempuh dengan jalan meningkatkan produksi tanaman pangan dan tanaman perdagangan mereka dan atau dengan menaikkan harga yang mereka terima atas produk-produk yang mereka hasilkan. 
Secara teoritis maupun empiris pertumbuhan sektor pertanian telah terbukti memberikan kontribusi nyata terhadap penanggulangan kemiskinan. Dalam perspektif ke depan, Asia diharapkan memberikan kontribusi terhadap GDP global sebesar 42 persen pada tahun 2015. Proyeksi tahun 2015 juga menunjukkan bahwa $3 / 4$ penduduk miskin masih berada di wilayah pedesaan.Pertumbuhan sektor pertanian harus dipicu dengan meningkatkan produktivitas dan produksi yang lebih tinggi, perluasan jaringan irigasi dan peningkatan produktivitas tenaga kerja.Ilmu pengetahuan dan teknologi juga memainkan peran penting dalam aspek ini.

Pertumbuhan sektor pertanian akan memberikan kontribusi besar terhadap penanggulangan kemiskinan apabila terjadi distribusi pemilikan lahan yang merata, teknologi baru yang dapat oleh para petani kecil, dan pembangunan infrastruktur pedesaan yang menghubungkan desa-desa ke pasar lokal dan mendorong petani supaya mampu melakukan diversifikasi kegiatan ke arah usaha-usaha non-pertanian di pedesaan. Pertumbuhan sektor pertanian tidak hanyamemberikan dampak positif dalam penanggulangan kemiskinan melalui peningkatanpendapatan usaha tani, tetapi juga dapat mendorong kegiatan sektor non pertanian di pedesaan.

Di Indonesia, sebagian besar penduduk miskin berada di daerah pedesaan dan mereka mengantungkan hidupnya di sektor pertanian, maka peran pertanian di Indonesia sangat jelas dalam penanggulangan kemiskinan.Dengan kata lain pertumbuhan pertanian merupakan salah satu kunci dalam penanggulangan kemiskinan. Program-program pertanian focus pada wilayah penduduk miskin atau pada wilayah yang berdampak positif terhadap penanggulangan kemiskinan pada wilayah itu.

Salah satu kebijakan dalam membangun pedesaan dan meningkatkan kesejahteraan petani adalah meningkatkan nilai tambah produksi pertanian dan nilai tambah tersebut sebagian besar dinikmati oleh petani.Atas dasar itu, sangat penting bagi pemerintah/DPR untuk menggalakkan pembangunan industry pertanian rakyat di wilayah pedesaan. Pembangunan infrastruktur di pedesaan atau wilayah pertanian, seperti pembangunan jalan-jalan desa, jaringan irigasi dan lain sebagainya, akan berdampak positif terhadap kelancaran distribusi dan atau pemasaran input dan output pertanian. Pada akhirnya dapat berdampak positir terhadap kegiatan pertanian dan peningkatan produksi. 
Selain itu peranan pemerintah dalam menangani perkembangan pertanian bagi pembangunan perekonomian yaitu dengan membuat kebijakan harga di sektor pertanian seperti kredit pada petani dan subsidi harga bahan pangan merupakan hal yang umum di negara-negara berkembang.Penggenaan dua tipe kebijakan harga tersebut, ditambah dengan pajak atas tanaman ekspor, jika tidak didasari informasi dan perhitungan yang tepat dan berhati-hati bisa jadi justru merugikan beberapa kelompok dalam masyarakat.

Dalam membangun pertanian yang lebih baik paling tidak pada tahap awal pembangunan, pertanian berperan mensuplai pangan, menciptakan kesempatan kerja, dan menyediakan pasar bagi produk-produk industri serta peningkatan kecerdasan para petani (pemberian pelatihan dan penyuluhan).Ditambah dengan pengembangan industri pedesaan, transformasi pertanian ke industri menjadi semakin lancar.Dan bantuan atau program pembangunan pertanian di Departemen Pertanian (Deptan) harus selalu dihubungkan dengan tujuan akhir, yakni membangun petani yang berdaya dan tidak tergantung pada bantuan pemerintah.Untuk itu pengembangan dan perluasan program berbasis komunitas, pemberdayaan masyarakat dan bersifat partisifatif perlu dilakukan.

\section{PENUTUP}

Dari pemaparan latar belakang, permasalahan, tujuan dan teori yang mendukung makalah ini hingga pembahasan mengenai transformasi dan peran pertanian dalam pembangunan ekonomi dapat kita tarik benang merah dari itu semua, bahwa sektor pertanian merupakan mata rantai terlemah dalam rantai pembangunan di negaranegara berkembang sehingga perlu mendapat perhatian khusus pembangunannya.

Ciri khas sektor pertanian adalah bahwa sepanjang proses pembangunan ekonomi, sektor ini mengalami transformasi. Tahap-tahap transformasi menurut Arsyad adalah tahap pertanian subsisten, tahap transisi, dan tahap pertanian modern.Ditinjau dari perekonomian total, transformasi terjadi dalam bentuk turunnya sumbangan pertanian dalam GDP dan kesempatan kerja yang di ciptakannya.Dalam mentransformasi sektor pertanian, negara-negara berkembang biasanya mengacu pola sejarah pembangunan negara-negara maju.Tetapi harus diperhatikan bahwa keadaan negara-negara berkembang saat ini.

Perubahan hubungan antara sektor pertanian dan non-pertanian dari sisi sumbangan pertanian terhadap pembangunan adalah; (1) pertanian menyumbang 
kebutuhan pangan bagi populasi non-pertanian, (2) sektor pertanian semakin mengurangi jenis tanaman pangan dan semakin banyak menanam jenis tanaman industri yang merupakan input dasar proses industri. (3) Sektor pertanian menyumbang faktor produksi berupa tenaga kerja dan modal. (4) ekspor pertanian dari waktu ke waktu merupakan sumber devisa untuk membeli peralatan kapital dari luar negeri serta mengimpor barang konsumsi yang tidak diproduksi di dalam negeri. (5) sektor pedesaan menyediakan sumber dana untuk investasi industri di perkotaan. (6) Meningkatkan permintaan akan produk industri. (7) Memperbaiki kesejahteraan penduduk pedesaan yang merupakan masalah utama pemerintah di negara-negara berkembang.

Kebijakan-kebijakan pembangunan pertanian satu dengan yang lain terpaksa harus saling bertentangan, misalnya, (1) untuk merangsang surplus pangan diperlukan harga yang tinggi, tetapi di sisi lain tingkat upah perekonomian yang tendah mensyaratkan harga pangan sector pertanian harus rendah. (2) untuk meningkatkan perolehan devisa, tanaman ekspor harus diperbesar, tetapi hal ini akan mengurangi produksi bahan pangan. (3) Pemajakan pertanian bisa meningkatkan hasil pajak pemerintah, tetapi hal ini akan menurunkan minat investasi petani.

Prioritas kebijakan meningkatkan produksi pangan bisa dilakukan melalui penggunaan teknologi.Tipe dan arah perubahan teknologi dipengaruhi olehkekuatan pasar dan riset yang didanai pemerintah.Selain riset dalam negeri, sumber kemajuan teknologi adalah transfer dari luar negeri.Program-program riset loKal di negaranegara berkembang dalam beberapa hal tidak tergantikan oleh teknologi hasil riset asing tersebut.

Pada dasarnya suatu perubahan pada bidang tertentu akan membawa dampak kepada perubahan di bidang lainnya. Dalam konteks globalisasi pada saat ini, perubahan yang paling mendasar memang melanda sektor ekonomi, dimana membawa akhibat kepada perubahan sektor sosial, tenaga kerja, maupun sektor-sektor lainnya.Sesuai dengan hukum perubahan yang mengatakan bahwa tidak ada sesuatu yang abadi kecuali perubahan itu sendiri, maka terjadinya transformasi struktural perekonomian jelas tidak bisa ditolak.

Akan tetapi dengan beberapa langkah sebagaimana dikemukakan diatas, diharapkan proses transformasi tersebut tidak akan menjerumuskan bangsa Indonesia kepada kondisi daya saing yang lemah, sebaliknya mampu memperbaiki kinerja 
ekonomi Indonesia yang telah lama diragukan banyak pihak. Dengan demikian, proses transformasi perekonomian tadi pada hakekatnya merupakan stimulator bagi bangsa Indonesia untuk menghilangkan berbagai hambatan internal yang ada, sekaligus menjawab tantangan-tantangan eksternal yang muncul secara efisien.

\section{DAFTAR PUSTAKA}

Arsyad, Lincolin, Ekonomi Pembangunan, Edisi Ketiga, 1987, Bagian Penerbit STIE YKPN, Yogyakarta

Arsyad, Lincolin, Ekonomi Pembangunan, Edisi Keempat, 2004, Bagian Penerbit STIE YKPN, Yogyakarta

Sukirno, Sadono, Ekonomi Pembangunan: Proses, Masalah dan Dasar Kebijakan, Edisi Kedua, 2007, Kencana Prenada Media Group, Jakarta

Hakim, Abdul, Ekonomi Pembangunan, Cetakan Kedua, 2004, Ekonisia, Yogyakarta

Irawan dan M. Suparmoko, Ekonomika Pembangunan, Edisi 5, 1995, BPFE-UGM, Yogyakarta

Clark, C.,1949,The Conditions of EconomicProgress, Macmillan, London

Meier, Gerald M. dan JamesE. Rauch, Leading issues in Economic Development, 2000, Seventh Edition, New York

Berry, sara,"The Food Crisis and Agrarian Changein Afrika: A Review Essay."African Studies Review, 1984, dalam Nafziger, 1997

Mahyudi, Ahmad, 2004, Ekonomi Pembangunan dan Analisis Data Empiris, Penerbit Ghalia Indonesia

Schiff, M, dan Valdes, A., 1982, dalam Colman, 1994, The plundering of Agriculture in developing Countries. 